\title{
Teachers' Competency in Implementation of Classroom Assessment in Learning
}

\author{
Norfarahin Bt. Mohd Zamri, Mohd Isa B. Hamzah \\ Faculty of Education, National University of Malaysia, Bangi, Malaysia \\ Email: farahinmohdzamri@gmail.com,isa_hamzah@ukm.edu my
}

How to cite this paper: Zamri, N. B. M., \& Hamzah, M. I. B. (2019). Teachers' Competency in Implementation of Classroom Assessment in Learning. Creative Education, 10, 2939-2946.

https://doi.org/10.4236/ce.2019.1012218

Received: October 21, 2019

Accepted: November 26, 2019

Published: November 29, 2019

Copyright $\odot 2019$ by author(s) and Scientific Research Publishing Inc. This work is licensed under the Creative Commons Attribution International License (CC BY 4.0).

http://creativecommons.org/licenses/by/4.0/

(c) (i) Open Access

\begin{abstract}
This paper discusses teachers' competencies in implementing classroom assessment in Malaysia primary schools. Source of skilled manpower in education is the main agenda of Malaysia in achieving the goals of Vision 2020. Education Ministry decided to making the values available on teachers' competency as a priority. Teachers' competence is a very important factor in implementing current and new policies in education. A good level of teachers' competence can realize the purpose and policy of education that is set up in the assessment. This assessment process requires all subject teachers as an implementer for collecting evidence about student learning. The main focus of this paper is on teachers' competencies in implementing classroom assessment by outlining the goal of making high-potential teachers as implementers to achieve the objectives of classroom assessment. The objective of this assessment is to get an overview of student performance and teachers can improve and make judgments about learning.
\end{abstract}

\section{Keywords}

Teachers', Competencies, Classroom Assessment

\section{Introduction}

This paperwork focuses on teachers' competencies in the assessment of an Academic School Based Assessment (CBA) category student. Academic category consists of two components which are Centralize Assessment and Classroom Assessment. These components should be executed in Primary School and Secondary School based on Examination Board Release (KP. LP.003.07.14.05) (1) volume 3 in 2011. Therefore, the Education Ministry of Malaysia always committed in planning reforms to make the curriculum become more effective for school administrators and curriculum practitioners in school. 
In today's learning environment, things are beginning to look more challenging. So, the Education Ministry decided on planning to implement more changes that could bring long-term sustainable effects. The first step was by removing the compulsory examinations for children aged seven, eight and nine at primary school (Ministry Education, 2018) in early 2019 to the new system classroom assessment. This ensures that the general development of the students is a priority, rather than just academic achievement. The main focus of the Ministry is the implementation of the assessment that should be continuous by way of formative and summative assessment in order to ensure the student development holistically. The assessment process may not be new in itself but may be new to the teachers and school concerned. Principle and standards are needed to guide the development of affective assessment practice. These should be designed to enable any stakeholder sustaining desirable changes in assessment and its use.

As an implementer, teachers need a high degree of competence in fulfilling the role and responsibility of achieving a good system of learning assessment. Classroom assessment is a process of collecting evidence about student learning by observing, scoring, interpreting the information and parents receive reports about students result. Parents may not be familiar with the assessment they are united in their desire to ensure great teaching for every child every day. Teachers competence is the most important school districts that have to meet this expectation.

Competency is a standard that determines the performance of an employee's service in performing their tasks (Ibrahim, 2015). In education, teacher competence is the standard set for teachers in mastering various educational competencies to meet current educational needs and enhance their competence in conducting assessments. In fulfilling the responsibilities of implementing the classroom assessment, the competencies required a professional judgment which includes knowledge, professional responsibility, experience and students' input (Sajali, 2018). These elements require knowledge, skills and a positive attitude of teachers to produce effective classroom assessment in schools.

\section{Problem Statement}

\subsection{Teachers' Competency}

Teachers' have a responsibility to ensure the new system of assessment in public school in Malaysia effectively help students learn at the highest level of the current world education development. Thus, teachers continually expand their knowledge and skills to implement the best assessment in the classroom in order to obtain good learning (Nawi, 2011). According to Rahman \& Mahamood (2017), curriculum planning and implementation require mastery in thinking and learning skills to produce students who can to solve life problems that are becoming more complex rationally. Many researches showed that teaching quality is the most important factor in raising student achievement. Curriculum innovation especially in assessing student's development by way of assessment needs a high de- 
gree of teacher competency (Hasnah 2017).

Sh. Siti Haizumah (2019) said that the teacher's quality rests on the competence of the teacher in determining the learning success and facilitation. A teacher's quality is a group of skilled, competent, qualified, passionate, committed and with the soul of an educator (Ministry of Education Malaysia, 2006). Therefore, it is clearly shown that teacher's competency is very important in implementing classroom assessment that is effective in order to fulfill the objective of the said classroom assessment.

Apart from that, competency in assessment should be preferred based on standards four of Learnings and Facilitating SKPMg2 by Quality Assurance of Education Ministry (2017); Teacher's role as an assessor. Teachers need to meet critical criteria as assessors to determine student's level of mastery. Teachers juggle an overwhelming number of unfamiliar issues in classroom based assessment such as instruction, curriculum, operations of the assessment, test preparation and administration, state standards and parent relations.

\subsection{Classroom Assessment in Learning and Facilitating}

Classroom assessments require a continuous process of Learning and Facilitation sessions to capture the student achievement. Classroom assessment involves the process of constantly collecting, analyzing and reflecting so that the needs of the curriculum can be improved through learning. Effective implementation of this assessment can provide a clear picture of students' performances and thus help schools, parents and teachers to plan follow-up actions to improve students' achievement in their learning.

Through this process, teachers need to play their part effectively in the implementation of the classroom asssessment to achieve its objectives. Teachers are responsible for producing outstanding and quality students through effective learning processes. However, research shows that teachers have low levels of competency in mastery of their subject's content, their pedagogical skills, resources, technology and communication (Hanafi \& Badusah, 2016).

Learning can achieve its objectives when learning involves two-way interactions between teachers and students (Mahamod \& Lim, 2011). Two-way learning can enhance students' thinking skills and resulting in high student mastery in learning and works given by teachers. However, there are many groups of teachers who are still not implementing two-way education to ease the implementation of assessment effectively even though the education system in Malaysia encourages it among the teachers to help students learn at the highest level.

Manda (2006) who stated that changes in teaching methods and pedagogy are important in efforts to improve the student's education. This effort needs to be continued because the current curriculum changes require a high level of commitment from the implementing teachers in order to optimize their role in the organization (Zamri Mahamod, Mohamed Amin Embi, \& Nik Mud Rahimi Mohd Yusoff, 2010). This cycle of continuous improvement ensure that teachers 
are constantly working to become more affective in addressing students' learning problems and improve students' achievement.

\section{Teacher's Competencies in Implementing Classroom Assessment}

Assessment based classroom is a new policy in Malaysia educational system and teachers takes years to gain the skills they need to be affective in their role. Professional judgment is a domain of competence that is best suited for classroom assessment needs (Kementerian Pendidikan Malaysia, 2018). Professional judgment is a judgment made using aspects of knowledge, skills, values, evidence of achievement, teaching strategies, assessment methods and established criteria.

In classroom assessment, teachers have to strengthen performance level of knowledge, experience, students' input and practice of professional responsibility. The main purpose is to ensure a student to learn and this is in line with the concept and purpose of implementing classroom assessment (Education Ministry, 2018) by way of formative and summative tests.

Competence in professionalism needs to be emphasized in order to produce quality teaching and learning (Hyvarinen, K. Saaranen, T. \& Tossavainen (2015). Therefore, the three professional competencies outlined by Ministry of Education need to be achieved by all teachers in the areas of knowledge, skills and attitudes in order to increase the value of professional practice (Kementerian Pendidikan Malaysia, 2015). The element in implementing professional consideration that needs the competence of a teacher (knowledge, skill and attitude) in the assessment are as follows:

\subsection{Curriculum}

Curriculum competency assessed based on the mastery of subject content, instructional method, test preparation, state standard and student learning needs. Nor \& Mahamod (2014) stated that an effective curriculum delivery came from a wide knowledge of a teacher on their current teaching subject. The teacher knows the criteria that has been set is the level of mastery, performance standard and standard curriculum document in the primary school standard curriculum.

Every teacher needs to have a wide range of knowledge in the subject taught and should always be improved to be in line with the current curriculum requirements. Teachers also should understand the basic concepts and the structure of subjects taught. According to Netherlands Teacher Educators, content competency is an important element in integrating quality education. The competency of teachers in the field of the curriculum is important in the implementation of classroom assessment.

Thus, the implications of teaching and learning can be achieved properly. This is because the main concept of assessment is to evaluate for the next learning 
process which involves enhancing the mastery and development of students. This is a basis of assessment in the development and management of curriculum policy in the school organization. The purpose is to improve learning for teachers and students.

\subsection{Pedagogy}

The competency of teachers in pedagogical greatly affects the implementation of classroom assessment. Effective learning involves an application of various learning methods to enhance the student's mastery and develop productive behaviors. The assessment should be applied in each pedagogical element that is being implemented nowadays. This is because effective teachers affect student. Student learning and achievement increase when teachers engange in affective assessment to address students learning challenges (Nawi, 2011).

A plan in teaching and learning activities should be established systematically so that the assessment can be implemented properly. The main aim of teaching is to make students study (Ariffin, 2008). This situation requires the teacher to plan carefully and appropriately so that effective learning succeeded (Hassan \& Meor Ibrahim, 1997). This matter was also supported by Azizah Lebai Nordin (1999) states that teachers need to have a preparation in the implementation of effective teaching through various teaching strategy applications.

Therefore, teachers need to make sure the implementation of assessment in the classroom because it helps teachers analyze student achievement data during the learning to immediately identify learning problems, develop solutions and promptly apply those solutions to address students' needs. Classroom assessment also can be useful if it takes place before classes begin or after they end.

\subsection{Professional Development}

According to Siraj, Ibrahim (2012) professional judgment is that teachers are actively involved in ongoing professional development activities. Teachers also need to contribute knowledge and skills to the teacher community. In that community, teachers should always be ready and willing to help other teachers in the educational profession. With extra support teachers learn more effective practices to apply to daily challenges. Additional support also helps districts retain teacher to the assessment and set them on the path to becoming effective stake holder.

This element is in line with Hedley in Esmali (2017) state that competent teachers are teachers who contribute professionalism aspects in education such as knowledge sharing and behavior by formal or informal contexts. Such as conference, seminar, collaborative learning among members and independent reading to improving teaching and students learn at the highest levels. Professional development is also the way teachers' can learn so that they are able to better their performance and raise student achievement (Mizell, 2010). In Malaysia, PLC has become as Continuous Professional Development's activity in 
producing responsible teachers in guiding students in their classroom. Teachers can enhance this competency through team members such as Professional Learning Community (PLC) that can help teachers improve their competence in professional judgment in an assessment.

Through these activities, teachers capable to exchange, share and disseminate information on problems and how to solve those problems in an organization (Aziah Ismail, Noraini Haron, \& Abdul Ghani, 2013). Therefore, every teacher should always strive to improve his or her self-esteem through the professional responsibilities established by the ministry. Policymakers, community leaders and teachers have a responsibility to ensure that educators engage in continuous professional learning and apply that learning to increase student achievement.

\subsection{Valuation}

Teachers act as assessors in SKPMg2's Standard 4 of learning and facilitating. Evaluation competence is an ability to evaluate student work and to analyze data collected through various assessment methods. Ibrahim (2015) states that analysis gained through assessment in learning is seen as a process of improving teaching and learning methods.

The quality standard of the role of teachers as assessors is that teachers are able to conduct the systematic assessments. To achieve the standard, teachers need to use a variety of assessment methods, perform rehabilitation and enrichment activities, give students assignments, reflect and review student work.

All actions to achieve this standard must be implemented by following with the lesson objectives according to the rigorous and effective implementation of the assessment by the teachers (KPM, 2018). The most effective teachers continue to strengthen their practice throughout their career and focus on the needs of students. Student learning and achievement increase when teachers engage in effective assessment focused on the skills teachers need in order to address students' major learning challenges (Ariffin, 2008).

\section{Conceptual Framework}

The conceptual framework below refers to the five domains of competence that are considered to have the greatest impact on improving teachers' performances in implementing classroom assessment during teaching and learning. In this study, the competencies are knowledge, skill and attitude in the implementation of classroom assessment (Figure 1).

Teachers' competence in Effective Classroom Assessment Implementation in this Conceptual Framework is made by the professional competencies that have been outlined by the Ministry of Education Malaysia which is the knowledge, skills and attitudes of the teachers. Whereas the domain for competency assessment is established through the competency domain required by new teachers. These two factors have been combined to form a conceptual framework for teacher competence in the implementation of classroom assessment. 


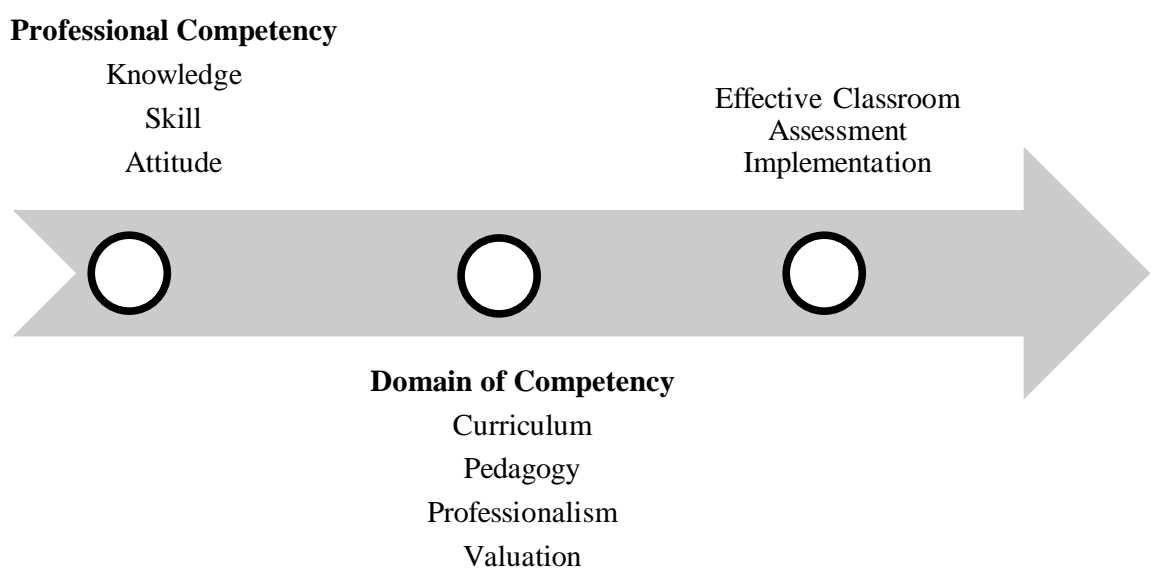

Figure 1. Conceptional framework.

\section{Conclusion}

Competency is an important factor in achieving the educational goals set by the Ministry of Education Malaysia. Competence is required to implement existing policies for improvement and new policies. The new policy created by the ministry is an initiative to create a world-class education. Ahmad (2014) stated that the success of learning depends on the competence of teachers. The most important factor contributing to a student's success in school is the quality of teaching. In the assessment, special competencies need to be developed within the teachers especially competence in meeting the requirements of an effective evaluation process to ensure a successful education experience for every student.

This paper focuses on the aspect of teachers' competence of the academic assessment which is Classroom Assessment. Teachers who are competent in implementing assessments will be able to achieve the objectives of the assessment to increase student achievement. Teachers must learn and solve problem in order to improve their performance and ensure all students achieve success. Effect in assessment affects students.

\section{Acknowledgements}

The research was partially supported by grant received from the Faculty of Education, Universiti Kebangsaan Malaysia code PP-FPEND-2019.

\section{Conflicts of Interest}

The authors declare no conflicts of interest regarding the publication of this paper.

\section{References}

Ahmad, A. (2014). Pengetahuan, Kefahaman dan Kemahiran Guru Bahasa Melayu terhadap Pelaksanaan Pentaksiran Berasaskan Sekolah (PBS) di Sekolah Menengah. Kertas Projek Sarjana Pendidikan. Fakulti Pendidikan, Universiti Kebangsaan Malaysia.

Ariffin, S. R. (2008). Inovasi dalam Pengukuran dan Penilaian Pendidikan. Bangi: Uni- 
versiti Kebangsaan Malaysia.

Aziah, I., Noraini, H., \& Abdul Ghani, K. (2013). Amalan Pembangunan Profesionalisme dalam Kalangan Guru Novis. Journal of Chemical Information and Modeling, 53, 1689-1699.

Esmali, B. (2017). Dasar Penempatan-Pertukaran, Kompetensi dan Tanggungan Tugas Dalam Perkhidmatan Guru di Sabah dan Sarawak. Kuala Lumpur: Universiti Malaya.

Haizumah, S. S. (2019). Knowledge, Skills, Attitude and Problem of Teacher's in Implementing Classroom Assessment (Vol. 9, Bil. 1, pp. 56-67). Putrajaya: Kementerian Pendidikan Malaysia.

Hanafi, N. Z., \& Badusah, J. (2016). Pentaksiran Berasaskan Sekolah Dalam Pembelajaran Bahasa Melayu di Sekolah Menengah. In Prosiding Seminar Pascasiswazah Pendidikan Bahasa Melayu \& Pendidikan Kesusasteraan Melayu Kali Kelima (pp. 539-546). Bangi: Penerbitan Fakulti Pendidikan Universiti Kebangsaan Malaysia.

Hassan, A., \& Ibrahim, M. (1997). Latihan Mengajar: Apakah Persediaan Guru Pelatih? Skudai: Universiti Teknologi Malaysia.

Ibrahim, M. S. et al. (2015). Strategi Implimentasi Pelan Pembangunan Pendidikan Malaysia. Kuala Lumpur: Universiti Malaya.

Kementerian Pendidikan Malaysia (2015). Panduan Pelaksanaan Program Pembangunan Guru Baharu.

Kementerian Pendidikan Malaysia (2018). Panduan Pelaksanaan Pentaksiran Bilik Darjah. Putrajaya: Bahagian Pembangunan Kurikulum.

Mahamod, Z., \& Lim, N. R. (2011). Kepelbagaian Kaedah Penyoalan Lisan dalam Pengajaran Guru Bahasa Melayu melalui Pemerhatian. Jurnal Pendidikan Bahasa Melayu, 1, 51-65.

Mahamod, Z., Embi, M. A., \& Yusoff, N. M. R. M. (2010). Penteaksiran Bilik Darjah: Panduan Untuk Guru Bahasa Melayu, Inggeris dan Arab. Bangi: Penerbitan Fakulti Pendidikan, Universiti Kebangsaan Malaysia.

Manda, D. A. (2006). Comments on Michael Fullan's the Future of Educational Change: System Thinkers in Action. Journal Education Change, 7, 133-135. https://doi.org/10.1007/s10833-006-0005-4

Mizell, H. (2010). Why Professional Development Matters. Oxford: Learning Forward.

Nawi, N. H. M. (2011). Pengajaran dan Pembelajaran; Penelitian Semula Konsep-Konsep Asas Menurut Perspektif Gagasan Islamisasi Ilmu Moden. Kongres Pengajaran dan Pembelajaran. Bangi: Universiti Kebangsaan Malaysia.

Nor, M. A., \& Mahamod, Z. (2014). Penterjemahan Pengetahuan Pedagogi Kandungan Dalam Proses Tindakan Guru Bahasa Iban Baharu dan Berpengalaman Bukan Opsyem. Jurnal Pendidikan Malaysia, 39, 37-49.

Nordin, A. L. (1999). Guru Pendidikan Islam Berkesan. Masalah Pendidikan. Jilid 22. Kuala Lumpur: Fakulti Pendidikan, Universiti Malaya.

Rahman, S., \& Mahamood, Z. (2017). Inovasi Pengajaran dan Pembelajaran Bahasa: Mengoptimumkan Pembelajaran Pelajar. Kuala Lumpur: Dewan Bahasa dan Pustaka.

Siraj, S., \& Ibrahim, M. S. (2012). Standard Kompetensi Guru Malaysia. In Prosiding Seminar Kebangsaan Majlis Dekan Pendidikan IPTS 2012 (pp. 1-44). Kuala Lumpur: Universiti Malaya. 